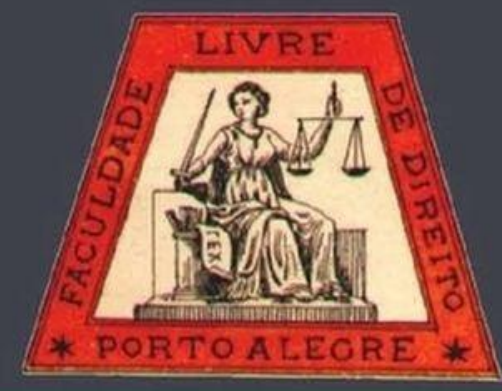

\title{
O verbo do Direito Liberal
}

\author{
The Liberal Law verb
}

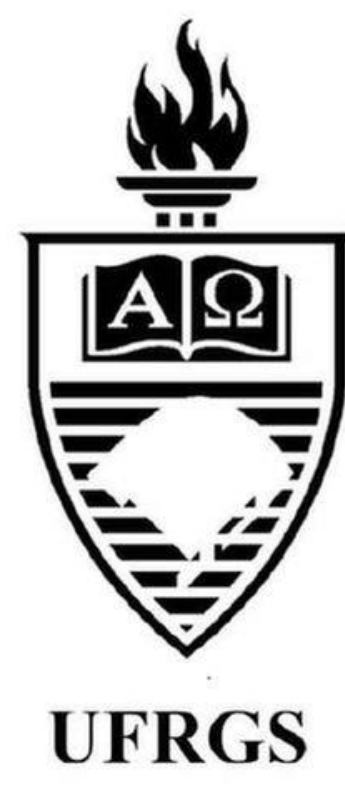

\section{Carlos Petit}

Universidad de Huelva 


\title{
O verbo do Direito Liberal ${ }^{* * *}$
}

\author{
The Liberal Law verb
}

Carlos Petit ${ }^{* * *}$

\section{REFERÊNCIA}

PETIT, Carlos. O verbo do Direito liberal. Revista da Faculdade de Direito da UFRGS, Porto Alegre, n. 39, p. 26-48, dez. 2018.

\section{RESUMO}

De uma parte temos o livro, depósito do saber, fruto da instrução e ainda de excelente conteúdo, porém a um passo do esquecimento; de outra parte, a palavra, forma imprescindível da substância posta por escrito, injeção de poder no saber livresco e, com isso, única garantia de longa vida. De modo que a palavra é poder e goza de duração; o escrito, coisificado inclusive como livro, sem a palavra se mostra volátil e impotente.

\section{PALAVRAS-CHAVE}

Verbo do Direito Liberal. Livro. Palavra. Orador.

\section{RESUMEN}

Por una parte tenemos el libro, depósito de saber, fruto de la instrucción y aun de contenido excelente, mas con todo a un paso del olvido; por otra parte, la palabra, forma imprescindible de la sustancia puesta por escrito, inyección de poder en el saber libresco y con ello única garantía de larga vida. De manera que la palabra es poder y goza de duración; el escrito, cosificado incluso como libro, sin la palabra se demuestra volátil e impotente.

\section{PALABRAS CLAVE}

Liberal Law verb. Book. Word. Speaker.

\begin{abstract}
On the one side we have the book, the deposit of knowledge, the fruit of instruction and still of excellent content, but it's one step from being forgotten; on the other side, the word, indispensable form of written substance, an injection of power into the bookish knowledge, and thus the only guarantee of long life. So the word is power and enjoys duration; the writing, even objectified as a book, without the word is volatile and impotent.
\end{abstract}

\section{KEYWORDS}

Liberal Law verb. Book. Word. Speaker.
Primeiro de outubro de 1859. Inaugura o curso na Universidade literária de Sevilha o professor Jorge Díez, catedrático "proprietário" de Literatura Latina, e conclui sua oração com uma apologia da palavra: "A um livro mal escrito não se prometa longa vida; por importante que seja a matéria de que trate, prontamente cairá no esquecimento... $\mathrm{O}$ homem cientista não vale somente por sua instrução: para valer e poder algo necessita também da palavra" ${ }^{1}$. Estas velhas e chocantes afirmações nos introduzem subitamente na tensão conceitual que articula minhas páginas. De uma parte temos o livro, depósito do saber, fruto da instrução e ainda de excelente conteúdo, porém a um passo do esquecimento; de outra parte, a palavra, forma imprescindível da substância posta por escrito, injeção de poder no saber livresco e, com isso,

\footnotetext{
* A amizade do Prof. Dr. D. Alfredo Flores (Porto Alegre) me permite reelaborar algumas páginas de meu livro - PETIT, C. Discurso sobre el discurso: Oralidad y escritura en la cultura jurídica de la España liberal. $2^{\mathrm{a}}$ ed. (1 ${ }^{\mathrm{a}}$ ed. 2000). Madrid: Universidad Carlos III, 2014 - com atualizações bibliográficas, acréscimos e alterações de vocabulário e estilo.

** Nota de tradução: o texto original em espanhol não foi publicado ainda nesse formato; conforme a nota anterior do autor, o presente texto resulta de uma modificação de publicação anterior. Tradução para a língua portuguesa: Denis Guilherme Rolla (Mestre em História do Direito, UFRGS). Revisão da tradução por Alfredo de J. Flores (Professor Permanente do PPGDir-UFRGS).

*** Catedrático da Universidad de Huelva, Espanha.

${ }^{1}$ DÍEZ, Jorge. Discurso leído el $1^{\circ}$ de octubre de 1859, en la solemne apertura del curso de la Universidad de Sevilla por... catedratico propietario de Literatura Latina. Sevilla: Imprenta y Librería Española y Extrangera, 1860.
} 
única garantia de longa vida. De modo que a palavra é poder e goza de duração; o escrito, coisificado inclusive como livro, sem a palavra se mostra volátil e impotente. Esse é o começo de que precisamos agora.

Certamente, o latinista Díez conhecia como ninguém em seu claustro o truque eficaz da antítese (palavra-escritura), a mensagem enfática de aliteração (valer-poder), a plasticidade retórica da sinédoque (onde palavra está por literatura). No entanto, em busca do horizonte cultural que possibilitou, há quase um século e meio, as manifestações anteriores, propõe-se aqui proceder a uma leitura algo mais ousada. Uma leitura diversificada, que descobre nos textos a vivacidade originária da voz humana.

Por exemplo, a que segue. "Em todas as nações cultas", podemos ler em outra oração inaugural, pronunciada por um colega jurista, Francisco de Borja Palomo, em 1867, "as artes de bem dizer foram o patrimônio das profissões científicas; porque não se concebe um saber profundo em qualquer matéria sem que lhe acompanhe o dote comum de expor as verdades daquela ciência com propriedade, correção, claridade e decoro, aspirando sempre à beleza que admita o assunto: uma para fixar a atenção do que nos ouve e gravar em seu ânimo a sentença; e outra para atrair leve e agradavelmente o espírito menos amigo ou mais oposto às ideias que expomos" $"$. O leitor dos velhos discursos também conhece algo a Cícero e recorda as advertências do advogado romano sobre a futilidade da sabedoria, que é muda e carece de vida ínsita na palavra, mas não parece útil concluir sobre a mesquinhez intelectual de um Palomo que silencia autoridades em sua lição de abertura simples e repousada glosa de motivos ciceronianos, com efeito - nem das frases

\footnotetext{
${ }^{2}$ PALOMO, Francisco de Borja. Discurso leido el día $1^{\circ}$ de Octubre de 1867, en la solemne apertura de estudios, por... catedrático numérario de Prolegómenos del Derecho, Historia y Elementos del Derecho Romano. Sevilla: J. M. Geofrín, 1867.
}

análogas de seu colega latinista, pois estes dois textos acadêmicos obedecem a uma tradição enraizada que coloca a sede do humano conhecimento nas artes oratórias. Desde esta perspectiva, as citações de autoridade seriam uma mera questão de ornatus francamente secundária para um público formado nas mesmas leituras do orador a quem escutava.

Antes de abandonar os discursos universitários pelos forenses, nosso principal argumento agora, convém aproveitar algo mais essa primeira fonte de informação, pois nos confronta com problemas gerais, assim como o tratamento prévio para uma incursão pelos textos do direito.

Nas universidades espanholas, como em qualquer estabelecimento de ensino público, o curso era inaugurado precisamente no dia primeiro de outubro e as solenidades de abertura incluíam a oratio de um catedrático nomeado pelo reitor em turno entre as faculdades; o mesmo que agora, "concluída a leitura, exemplares impressos deste documento serão distribuídos entre os indivíduos do claustro e demais pessoas convidadas". E então começaram os ensinamentos, cujo desenvolvimento supunha um constante exercício de atividades verbais. Lembro agora, pela sua expressividade, a prática das chamadas "academias" 3 , aulas especiais realizadas em todas as quintas-feiras com a assistência de catedráticos, segundo um rígido procedimento. No caso dos estudos jurídicos, onde se ofereceu por vários anos uma disciplina específica de "Oratória forense", o ensino de academia, devedor até em suas formas da

3 TORRES CAMPOS, Manuel. De la reforma de la enseñanza del Derecho en general y en particular de las Academias. Discurso leído en la sesión inaugural del curso de 1890 en la Universidad de Granada. Revista de los Tribunales, n. 22, 1891, p. 116-119, 128-135. 
controvérsia característica do processo, alcançou certamente a dimensão mais apropriada ${ }^{4}$.

As academias permitiram aprofundar conhecimentos e inculcar receitas oratórias, com o que facilitavam ante a ansiedade dos exames provas orais, evidentemente - mas também preparavam para a colação de graus. Será suficiente recordar que o máximo de todos, o grau de doutor - que só dispensava Madri (Universidad Central de España), obtinha-se com um ano a mais de estudos e a preparação de um discurso, solenemente declamado ante o claustro universitário. Faríamos mal em confundir essas intervenções cerimoniais com nossas modernas teses - um termo tardio que não aparecerá até as reformas educacionais do Ministro Germán Gamazo (1883). De entrada, os doutores não tinham muita liberdade para escolher o argumento de suas dissertações, pois durante muitos anos se restringiam à lista de temas aprovada pela Faculdade. A extensão do discurso também era limitada pela regra segundo a qual a sua declamação não poderia exceder a meia hora. $\mathrm{E}$ a "pompa" social do ato, isto é, a assistência de altas autoridades (o Ministro de Desenvolvimento impunha as suas insígnias), mais um grande número de curiosos convertiam o doutorado em uma brilhante representação sem pretensões de ciência 5 .

A ausência de tais pretensões resulta então, antes que uma carência institucional, uma característica própria dos usos eloquentes da universidade isabelina. Ao mesmo resultado

\footnotetext{
${ }^{4}$ Conheço, por exemplo, o programa inédito de Oratória elaborado por Manuel López Gómez (1823-1893), catedrático (de várias matérias: Disciplina eclesiástica, Direito canônico, Direito civil, Direito Internacional Público e Privado), desde 1851, na Universidade de Valladolid. O manuscrito (Valladolid, 16 de abril, 1868) se conserva em seu expediente pessoal - Archivo General de la Administración (Alcalá de Henares, Madrid), signatura 31/16059 e se divide em 69 lições com dois grandes apartados ("Preliminares": lec. 1-28; "Eloquência forense", lec. 29-69). Uma nota final precisa: "Sempre que o interesse das lições o requeira, praticar-se-ão exercícios de análise sobre os bons modelos latinos e espanhóis, invertendo-se os
}

chegamos ao repassar os sistemas de provisão de cátedras, isto é, o mecanismo espanholíssimo das oposiciones, cujo estatuto administrativo respondia completamente à oralidade do ensino

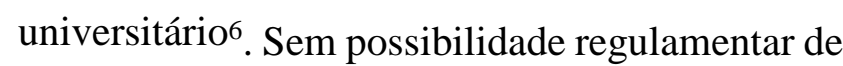
apreciar os "méritos literários" dos candidatos, as cátedras eram preenchidas entre aqueles doutores que demonstrassem melhor memória e facilidade de palavra, com ampla capacidade de improvisação.

Buscava-se, em outros termos, ao professor que pudesse desempenhar a delicada missão de levar a voz da universidade à sociedade e ao Estado, assunto este de verbo corporativo que documentam com rara eficiência precisamente as lições inaugurais: era de estilo advertir que o catedrático oficiante se limitava a falar pela universidade. A natureza corporativa do ato aparecia ainda na designação por turno do orador, um extremo que conspirava contra sua singular pessoa e sua livre disposição do verbo institucional. E tudo isso fazia, para o alívio do conferencista isabelino, que a consciência da própria pequenez, o desmaio oratório ou a grande ignorância (motivos inevitáveis nos exórdios) nunca impediram subir à tribuna ou dissertar para um público esclarecido.

Desde o ponto de vista dos conteúdos, a lição inaugural oscilou entre a exposição de algum ponto relativo à especialidade do orador (sempre entendido muito geralmente) e a leitura de um discurso inespecífico. A renúncia ao próprio saber em benefício comum não parece ter

dias letivos sobrantes, em exercícios e ensaios oratórios e no repassado em geral".

5 Temos agora um completo catálogo das teses/discursos de Doutorado em Direito, com um estudo introdutório que analisa a questão: MIGUEL ALONSO, Aurora; MARTÍNEZ NEIRA, Manuel et al. Doctores en derecho por la Universidad Central: Catálogo de tesis doctorales 1847-1914. Madrid: Dykinson - Universidad Carlos III, 2018.

6 MARTÍNEZ NEIRA, Manuel. La regulación de las oposiciones a cátedras universitarias: 1845-1931. Madrid: Universidad Carlos III, 2014. 
causado um sacrifício doloroso, mas as mudanças científicas e a mentalidade tipográfica que só se consolidam no fim do mesmo século nos deixaram lições que contêm a crônica de um rigoroso, "moderno" exercício profissional.

Até esses tempos de empenho científico, a lição permaneceu fiel às suas origens. Nasce, cresce e vive por e para a universidade, que a imprime à sua ordem e seu custo, e a reparte junto à memória estatística anual da educação pública no distrito como único produto impresso das atividades institucionais. E se vigia o estilo: os discursos tinham de ser "escritos no tom e na forma que corresponde à importância do ato oficial" (R. O. 12 de outubro, 1849) - onde a ênfase na forma, que revela uma vez mais o entendimento meramente oratório da vida universitária, deve ser estendida também à substância da lição, por ser condição indispensável que se "entregue o manuscrito ao Reitor [...] com oito dias de antecipação, a fim de que o examine e autorize a sua leitura e impressão, se não encontrar inconveniente nisso, ou faça as correções que estime necessárias". A disposição nos resulta hoje um terrível ato de censura, mas em sua época significou uma manifestação, certamente obrigada, da titularidade corporativa do verbo universitário.

A existência de trâmites de censura serviu desde logo para que certas opiniões radicais nem sequer passassem da mente para a garganta em momentos em que desconheciam a liberdade educativa, mas, mesmo assim, não creio que deveríamos simplesmente dispensar esse assunto dos controles institucionais que gravitavam sobre as lições. A festa de abertura do curso acadêmico, a circunstância dessas lições, impunha uma certa disciplina. Em primeiro lugar, porque, de acordo com um higienista francês bem conhecido pelos

\footnotetext{
${ }^{7}$ RIANT, A. Hygiène des orateurs, avocats, magistrats, hommes politiques, prédicateurs, professeurs, artistes, et de tous ceux qui sont appelés à parler en public. Paris: Baillière et Fils, 1888.
}

oradores espanhóis, nunca se diz o mesmo revestido da toga que em um vulgar traje de rua, o que outorgou sentido à insistência no uso de roupas oficiais que apresentavam os discursos inaugurais ${ }^{7}$. Quando menos, a toga conspirava contra a personalidade do portador: seus gostos estéticos, suas preferências no vestir e conformar a própria imagem ficavam ocultos sob as roupagens do regulamento, onde apenas destacava, com cores improváveis e insígnias brilhantes, a pertença a uma faculdade e a posse de um grau corporativo ${ }^{8}$.

Se ao Estado lhe interessava tudo quanto pudesse dizer-se em sua instituição, a universidade como tal vigiou (e aí quisera agora focar no problema da censura nos discursos) o cultivo dos valores coletivos. Começando pela fé e a religião, que os laureados juraram guardar no momento da obtenção do grau: antes que um direito individual ao próprio credo ou confissão oficial do Estado, a religião jurada pertencia à própria vida da corporação, e nossos discursos o aceitaram. Aqui parece suficiente acrescentar que o motivo religioso, tão frequente na literatura acadêmica, naturalmente germinou e se converteu no amor respeitoso que deveria existir entre todos os universitários.

A censura das lições ou de uma oração doutoral se nos apresenta, então, como o instrumento mais útil que o reitor tinha em suas mãos para cortar opiniões demasiado pessoais ou formas improcedentes que envenenassem o claustro. E os catedráticos admitiam na sessão de abertura que "impugnar uma opinião, ou defender um sistema não cabe [...] a uma reunião, que não está congregada para científica polêmica [...] celebrando-se hoje essa simpática solenidade, em que se abrem novamente as portas do templo sereno, onde não reinam paixões tumultuosas" $"$.

${ }^{8}$ A disposição principal, em uma série algo longa, aberta em 1835, foi o Real Decreto de 6 de março, 1850.

${ }^{9}$ LÓPEZ SÁNCHEZ, Pedro. Discurso leído por el Dr. ... Catedrático numerario de la Facultad de Derecho ante el claustro de la Universidad de Salamanca el día $1^{\circ}$ de 
A atuação do reitor em censura do discurso não seria, pois, outra coisa que uma vigilância paternal sobre a emissão responsável da voz corporativa.

Tornada pública para desfrute coletivo, convertida logo em texto de titularidade compartilhada entre a universidade e o catedrático, a lição de abertura de curso é boa mostra de uma cultura que não reduziu a letra impressa os seus melhores instrumentos de difusão. Se a universidade liberal produziu algum livro, trata-se de apontamentos e notas que passaram diretamente do auditório para a gráfica: subprodutos de "textos vivos" que não sabiam nem queriam renunciar a sua primitiva expressão oral ${ }^{10}$. Desde o ponto de vista que nos interessa, a forma eloquente do saber implicava elevar a advocacia, secularmente celebrada como máxima expressão e modelo de todas as prestações oratórias, à categoria ontológica onde reinava solitário o orador perfeito.

Não era, desde logo, o catedrático, quem se sabia uma peça necessária, embora humilde, para dispensar aos futuros letrados uma educação jurídica rudimentar. Tampouco parece que o juiz disputara com o advogado a primazia, mesmo que somente fosse pelo ilustre parentesco que unia a profissão forense com a eloquência judicial dos Demóstenes e dos Cíceros. Destes se tomou, em qualquer caso, um entendimento amplíssimo da atividade eloquente, convertida ainda na melhor possibilidade de exercício cidadão. $\mathrm{O}$ advogado não só resultou o jurista por excelência; não só foi seu discurso a expressão mais acabada da palavra posta ao serviço coletivo. Ante a falta de outra

Octubre de 1864 en el acto solemne de la inauguracion de los estudios del curso académico de 1864 á 1865 [Importancia de los crecimientos en la vida científica que se comunica de maestros á discípulos segun ley histórica y nociones filosóficas]. Salamanca: Diego Velázquez, 1864. p. 6 . sede mais adequada, dir-se-ia que os valores e os compromissos cívicos da profissão foram codificados nos tratados de oratória forense (Sainz de Andino, Sauri, Pérez de Anaya, Joaquín María López, León y Olarieta, Olózaga, Ucelay, Corradi, López Muñoz...) carregados de uma ideologia disciplinante com alto sentido constitucional, para que "a palavra [...] é a imagem do pensamento e o veículo de sua comunicação [...] grande nó que enlaça a sociedade [...] A boa ordem no uso da palavra é a base da civilização e é o sinal característico que distingue as tribos selvagens das nações cultas [...] Nem instituições sociais poderiam ter sido formadas: nem poderiam ser discutidas e estabelecidas leis justas e convenientes: nem fundamentar e exercer a ação e poder do governo: nem inspirar e propagar as máximas religiosas e morais: nem ensinar as ciências e utilizar o progresso do entendimento humano sem que se adotassem e reconhecessem regras no exercício da palavra" "11. Orientados por esse empenho político, os tratados de oratória apresentavam o catálogo de saberes que deveria atesourar o advogado. Interessava desde logo o direito, mas estamos ante uma condição que se dava por suposta, necessária, ainda que insuficiente para o correto desempenho da profissão forense; expressado nos termos clássicos de nossos autores, diríamos simplesmente que a ciência jurídica, a sapientia ou (ainda melhor) a ratio nutrida de leis a suprir o jurista liberal tinha que estar acompanhada da eloquentia, quando aspirava a render um autêntico serviço à sociedade e ao Estado.

${ }^{10}$ E a coleção de "Clásicos e inéditos del Derecho público español", editora Athenaica (Sevilha), dirigida por Sebastián Martín, esforça-se na recuperação desses textos verbais. Cf. por exemplo: FIGUEROLA BALLESTER, Laureano. Derecho político comparado: Lecciones de la Universidad Central, 1859-1860. "Prólogo" de Víctor J. Vázquez.

${ }^{11}$ SAINZ DE ANDINO, Pedro. Elementos de elocuencia forense (1827). $4^{\mathrm{a}}$ ed. Madrid: Imprenta de la Sociedad de Operarios del mismo Arte, 1847. p. XXXVI-XXXVII. 
Ao menos, o advogado combinava como ninguém certos dotes naturais (peito robusto, fisionomia digna, voz formosa - para Sainz de Andino; gênio, boa memória, boa figura, voz sonora e agradável - na versão de Joaquín María López $)^{12}$, utilíssimas para lograr eficaz presença pública mediante a palavra, com a prática continuada daqueles deveres e faculdades morais (probidade, veracidade, desinteresse, firmeza de caráter, amor à justiça - Sainz de Andino; honradez, laboriosidade, virtude, independência e firmeza de caráter, valentia, prudência, memoria, desprendimento e, acima de tudo, veracidade e 'calma fria' - Joaquín María López) dos que pende a conservação da república: na convicção de quem se sabe ao serviço de uma causa justa se resume a distância que distingue o bom orador do puro sofista ${ }^{13}$.

Agora, se as qualidades outorgadas pela natureza poderiam melhorar-se e deveriam conservar-se mediante a arte (e nossos tratados insistem na importância que haveria para o advogado a declamação de poesias ou os cuidados da voz, "correio fiel da nossa alma [...] ministro que publica seus pensamentos, suas intenções e sua vontade") ${ }^{14}$, as faculdades morais do advogado se exercitavam com o estudo constante e a aquisição de um habitus profissional na faculdade de Direito, as práticas de academia, a fraternidade própria de colégios de advogados. Aí encontrou sentido a posição algo paradoxal que as corporações de letrados parecem ocupar (com

\footnotetext{
${ }^{12}$ SAINZ DE ANDINO, Elementos de elocuencia, p. 10 et seq.; LÓPEZ, Joaquín María. Lecciones de elocuencia en general, de elocuencia forense, de elocuencia parlamentaria y de improvisación. T. I-II. Madrid: Imprenta que fue de la Sociedad de Operarios, ahora de D.M. Gabeirós, 1849-1850. p. 30 et seq. (tomo I).

${ }^{13}$ SAINZ DE ANDINO, Elementos de elocuencia, p. 13 et seq.; LÓPEZ, Lecciones de elocuencia, I, p. 18-19, 229 et seq.

${ }^{14}$ SAINZ DE ANDINO, Elementos de elocuencia forense, p. 178 et seq. Interessa-nos observar que a ginástica da voz se resolvia ao final numa vida altamente disciplinada, modelada segundo a ética que o advogado deveria ter sempre presente e que agora aparece sob a espécie de
}

seus renovados privilégios, suas limitações à ingerência externa, seu exercício de potestade disciplinar) nos tempos igualitários do Estado e do mercado: umas corporações toleráveis, e ainda necessárias por tratar-se de escolas de moral cívica que velavam pelo decoro de uma nobre profissão; certamente privada, mas consagrada por inteiro ao bem-estar público e à justiça ${ }^{15}$.

Mas a oratória forense ainda era entendida como um saber de saberes, uma expressão enciclopédica de receitas morais, artes comunicativas e conhecimentos de fundo: uma "divinarum atque humanarum rerum notitia" na definição do Digesto, que retomavam a esse propósito os preceptores isabelinos. Segundo unânime recomendação de suas obras, o advogado necessitava, em particular, "aparte desses estudos fundamentais... [i.e. filosofia, moral, história] dedicar-se a ler os poetas e outras obras de gosto e de imaginação que despertem e sirvam de tipo à sua [...] Esta é a primeira necessidade de todos os oradores [...] mas o advogado que deseja adestrar-se nas lutas do foro, precisa mais do que qualquer outro esta leitura frequente e meditada" 16 . Com admirável coerência, pelas datas em que se difundiam tais recomendações (1849), os planos de Direito incluíam um chamado "curso preparatório" nas faculdades de Letras, nutrido dos mesmos conhecimentos (latim, história, filosofia, literatura) que recomendavam convencidos os tratadistas de eloquência ${ }^{17}$.

conselhos carregados de escrúpulos morais, pois "el medio mas eficaz para conservar una buena voz consiste en tener una vida arreglada, y moderar el uso de los placeres sensuales. Los escesos en la comida, bebida y coito carnal, el desmedido trabajo y las velas prolongadas y repetidas estenúan rápidamente la voz, y acabarían con ella si se hiciesen habituales".

15 Cf. agora: MUÑOZ MACHADO, Santiago (ed.). Historia de la abogacía española. T. I-II. Pamplona: Aranzadi, 2015.

${ }^{16}$ LÓPEZ, Lecciones de elocuencia, I, p. 227.

${ }^{17}$ MARTÍNEZ NEIRA, Manuel. El estudio del Derecho: libros de texto y planes de estudio en la universidad 
Parece-me que o estudo acadêmico de letras nas faculdades de Direito e a assídua leitura da poesia, recomendada pelos tratadistas do foro para saber declamar um discurso com a adequada ênfase e a boa dicção, exercitar a memória e aprender figuras de linguagem, não foi um adorno erudito nem uma mera manifestação de status. Pelo contrário, a fruição literária era um dever profissional de advogados, arraigado na tradição eloquente. E é o que a poesia lhes oferecia, em primeiro lugar, palavras e estilos formosos que compensavam a aridez dos materiais legais, e nossos tratados o celebram: "ao orador forense é mais necessário que a nenhum outro consagrar-se ao estudo das belas letras, se ha de neutralizar estas influências destruidoras, e respirar livremente em meio desta atmosfera gelada, de completa esterilidade para a imaginação" ${ }^{18}$.

Como entre a poesia e os clássicos havia uma linha tão fina que nossos autores cruzavam sem escrúpulos, suas obras aconselharam, em segundo lugar, uma leitura poética que incluísse aos grandes oradores de todos os tempos: os discursos famosos do passado, mas até os mesmos modos pedagógicos dos antigos deveriam inspirar ao advogado isabelino: "um dos estudos que mais deve fazer o orador é dos discursos dos que lhe precederam [...] Os discursos de Demóstenes, Cicero, Mirabeau, General Foy, são bons modelos, e não devem ler-se, senão copiar-se e aprender de memória as melhores passagens. E não se desdenhe por pueril este trabalho. Demóstenes copiou a Tucídides até oito vezes, e bem se deixa conhecer no cortado e enérgico de sua dicção"19. Se introduzia assim uma disciplina de leitura que convertia a experiência poética do orador forense em um singularíssimo desfrute do

contemporánea. Madrid: Dykinson - Universidad Carlos III, 2001.

${ }^{18}$ LÓPEZ, Lecciones de elocuencia, I, p. 228. Cf. também: PÉREZ DE ANAYA, Francisco. Lecciones y modelos de elocuencia forense, estractadas las primeras de los mejores autores, ordenadas y reducidas á un tratado completo; escogidos y reunidos los segundos por... T. I-IV. Madrid: Imprenta de Baltasar González, 1848-1849. p. 142 (tomo I). texto. Como vemos, os poemas tinham de ser copiados uma e outra vez até converterem-se em puras palavras incisas na memória, destinados ao consumo verbal do jurista eloquente. E assim também se prescrevia uma sorte de leitura que ruminasse e deglutisse na cabeça as expressões e ideias do autor favorito: esse "ir dando diferente giro a todos os períodos da obra que se lê" que dizia Joaquín María López ${ }^{20}$, onde encontrava o jovem advogado a via média mais eficaz para lograr, a um tempo, o respeito devido aos maiores e o desenvolvimento de um estilo pessoal.

Orientados a essa última finalidade, ocultando apenas uma nova, terceira exigência favorável à poesia, os tratados se detinham ainda em propor ao advogado contínuos exercícios de tradução. A importância atribuída à tradução supõe pelo menos duas coisas. De um lado, tratava-se de aplicar a velhíssima pedagogia de aprender com exemplos, pois os clássicos latinos, mas também as glórias (francesas) do foro moderno comunicavam seu saber a quem se dedicara a traduzir e meditar os discursos; de outro lado, encontramo-nos ante uma poderosa razão que explicaria por si só a presença do latim e a literatura nos planos universitários de Direito. E assim, o gosto pelas traduções fez com que os autores latinos percorressem nosso século XIX em versões de advogados e políticos eminentes, com a mostra tão significativa (pois, como se sabe, é uma suma de conselhos de retórica) que aportou a epistula ad Pisones: reduzida a metro castelhano (junto ao resto das obras de Horácio) pelo famoso Javier de Burgos, que dividiu Espanha em províncias, e outra vez traduzida e versificada pelo não menos famoso Francisco Martínez de la Rosa, viva encarnação do

${ }^{19}$ LÓPEZ, Lecciones de elocuencia, I, p. 33. Cf. LEÓN Y OLARIETA, Fernando de. Consideraciones filosóficas, sobre la elocuencia forense. Esplicaciones dadas por don... Valencia: Imprenta de El Valenciano, 1862 - o autor insiste, de sua parte, em "la lectura de los autores clásicos y el aprender de memoria los mejores pasajes de los mismos... pues... se aprende por imitacion" (p. 43).

${ }^{20}$ Lecciones de elocuencia, I, p. 22. 
moderantismo. Ainda posso mencionar uma terceira tradução, que apresenta o mérito ou a extravagância acrescida de contar menos sílabas que a composição original do poeta neotérico, publicada com notas eruditas por um presidente de sala do Tribunal Supremo de Justiça ${ }^{21}$.

De maneira que o cultivo da poesia e o exercício de traduções foram um dever profissional característico dos do foro ${ }^{22}$. Assim sucedeu singularmente no caso de um de nossos preceptores, o político e advogado Joaquín María López, protótipo de homem de leis da Espanha isabelina e autor de uma dilatada obra literária ${ }^{23}$. Mas, ao lado de López, como não colocar de imediato ao sevilhano Joaquín Francisco Pacheco, sem dúvida um dos principais juristas da época, a quem devemos nada menos que a introdução da imprensa jurídica na Espanha? Pois bem, a última obra publicada por Pacheco foi uma ampla coleção miscelânea de Literatura, historia y política (1864), cujo prólogo o velho advogado e político evocava as ilusões de sua juventude: “a par do latim, da filosofia e das matemáticas, devorávamos as poesias de Melendez e as Comédias de Calderón; entre uma dissertação sobre a tutela e outra sobre o direito de preferência, brotava de nossa mente um romance descritivo, uma ode à liberdade da Grécia, ou um ato de tragédia da Escola de Racine. A arte e a literatura eram nosso deleite e nosso amor: um porvir artístico e literário, uma reputação de

\footnotetext{
${ }^{21}$ CASTRO Y OROZCO, José de. Arte Poética de Horacio. Reducida a menos sílabas. Manuscrito anónimo, publicado y anotado por Don... Marqués de Gerona. Barcelona: Tipografía de Narciso Ramírez, 1865.

${ }^{22}$ E não somente no sul da Europa - para os Estados Unidos, cf.: FERGUSSON, Robert A. Law and Letters in American Culture. Cambridge (Mass.): Harvard University Press, 1984.

23 LÓPEZ, Joaquín María. Colección de discursos parlamentarios, defensas forenses y producciones literarias. T. I-VII. Madrid: Manuel Minuesa, 1856-1857. Cf. também, entre muitos outros - CASTRO Y OROZCO, José de. Obras poéticas y literárias. T. I-II. Madrid: M. Rivadeneyra, 1864-1865.
}

poeta, eram nosso ideal, nosso anelo, nossa esperança" 24 .

Ante manifestações desta natureza, parece-me claro que a matriz verbal dos textos jurídicos e a aflição oratória explicam e se entendem, a um tempo, a partir da produção literária dos juristas isabelinos ${ }^{25}$. Não o foram talvez por causa de seu argumento, mas os versos de López e Pacheco ou as admiradas traduções de Javier de Burgos se convertem em textos jurídicos se os julgamos desde a necessária preparação ao exercício do foro e o bem dizer da tribuna: pois, nos termos categóricos de Joaquín María López, "o advogado deve ser eloquente quando escreve e quando fala" 26 .

Mas o próprio do forense sempre foi o segundo. Tenho especialmente presente o primeiro entre os advogados de Espanha: Manuel Cortina (1802-1879), erudito de Sevilha, deputado do partido progressista, ministro fugaz, presidente da comissão de códigos, decano do colégio de Madri (desde 1848 até sua morte, causado "por um infecção bronquial, tão comum naqueles que vivem pelo exercício da palavra" ${ }^{27}$ e mestre do verbo forense de acordo com os estilos do que se chamava, como se de tourada se tratasse, a "escola sevilhana": as sessões da Audiencia local, onde Cortina tinha apresentado as suas primeiras armas, "eram vistas como escola de eloquência prática [...] o público concorria a elas não por interesse para com alguma das partes que litigam, mas por escutar os brilhantes

${ }^{24}$ Literatura, historia y política. T. I-II. Madrid: Antonio San Marín - Agustín Jubera, 1864. Cf. I, p. VII.

${ }^{25}$ Cf. ÁlvareZ ALONSO, Clara. Perfil del jurista romántico español (1834-1855 ca.). In: CONDE NARANJO, Esteban (ed.). Vidas por el Derecho. Madrid: Dykinson - Universidad Carlos III, 2012. p. 289-327.

${ }^{26}$ LÓPEZ, Lecciones de elocuencia, I, p. 239 et seq.

27 UCELAY, Enrique. Estudios sobre el foro moderno. Conferencias dadas en la Real Academia de Jurisprudencia en el curso de 1882 á 1883 seguidas de biografías y defensas de abogados célebres españoles. Madrid: Viuda de J. M. Pérez, 1883. p. 167. 
perorações [...] como se assistisse a um espetáculo teatral" ${ }^{28}$. Da famosa mania deste Cortina "contra a publicidade" (na minha opinião, uma superlativa mostra de respeito pela oralidade do trabalho forense por parte do decano de Madri) dava ainda perfeita conta uma anedota recolhida por Ucelay (p. 108) sobre um pleito ante o Tribunal Supremo, onde Cortina interveio frente a Cristino Martos, assessor da parte contrária. Desejando essa parte (o sevilhano Fernando Espinosa, conde de Águila: de nobre estirpe erudita e de cultura liberal) conservar o relatório de seu advogado, solicitou e obteve da sala, contra o critério de Cortina, a permissão para transcrever taquigraficamente os discursos. Ante a falta de coisa melhor, Ucelay inclui em seus Estudios sobre el foro moderno, graças a um aporte documental que the chegou do conde, a réplica de Cristino Martos à negativa de Cortina ante sua proposta; em substância, Martos renunciou como bom cavalheiro do foro à permissão concedida no que fazia as palavras de seu relutante colega, limitando-se a deixar transcrever as próprias intervenções. (Por isso se irritou muitíssimo quando o hábil Cortina lhe jogou na cara durante o julgamento que a tomada de notas da alegação de somente uma das partes implicava a pior condição processual da outra; a coisa se endireitou depois, com Martos na junta colegial sob a presidência paternal de Cortina).

De Cortina, em conclusão, as gerações mais jovens só poderiam falar de ouvido: que pena que não se publicaram suas prestações

\footnotetext{
${ }^{28}$ São manifestações que tomo da biografia de Cortina PASTOR DÍAZ, Nicomedes; CÁRDENAS, Francisco de. Galería de Españoles célebres contemporáneos, 1843 (agora consultada em: HERRERO MEDIAVILLA, Víctor. Índice biográfico de España, Portugal e Iberoamérica. $2^{\mathrm{a}}$ ed. München: Saur, 1995) - dois conhecidíssimos oradores e advogados com grande sensibilidade, em meio de um relato em que predominam, contudo, as anedotas políticas, pela aprendizagem oratória de Cortina. Eu mesmo estudei o personagem, de quem - coisa extraordinária - conservamos biblioteca e arquivo profissional: PETIT, Carlos. Biblioteca, archivo, escribanía. Portrait del abogado Manuel Cortina. In: CONDE NARANJO, Esteban (ed.).
}

forenses, que jaziam em notas nem sempre legíveis, entre os documentos de seu arquivo ${ }^{29}$. Para a formação do advogado, além de ler e estudar os tratados do gênero, exigia conhecer os grandes modelos da profissão, desde os clássicos e retóricos do "foro antigo" (Demóstenes, Cícero, Quintiliano), até os colegas (franceses) do "foro moderno" (d'Aguesseau, Boucher d'Argis, Dupin, Camus, Berryer ...). Colocados neste plano, dir-se-ía que seria possível a um jovem advogado liberal estabelecer uma espécie de diálogo intemporal entre uns e outros. Entretanto, a julgar pelos livros de oratória mais tardios, a reflexão sobre os estilos do foro abriu fissuras na comunhão ideal do advogado com os antigos romanos - tão presente nas obras da primeira metade do século - até chegar ao abandono final ou, pelo menos, ao descrédito e à irrelevância, do receituário secular que servira para compor um relatório perante o tribunal ou uma especulação jurídica qualquer.

No entanto, a impressão que se obtém da obra de Enrique Ucelay - um par de tratados/antologias aparecidos nas últimas décadas do século, nascidos de atividades docentes - não é coisa tão nítida ${ }^{30}$. $\mathrm{O}$ culto ao "foro moderno" colidia com a experiência, extraordinariamente temporária

$\mathrm{e}$ irremediavelmente volátil, da palavra improvisada: resultava ser um problema insolúvel o saber ou poder capturar as energias

Vidas por el Derecho. Madrid: Dykinson - Universidad Carlos III, 2012. p. 329-386.

${ }^{29}$ Mas algo saiu impresso: PETIT, Biblioteca, archivo, escribanía, p. 354-356.

${ }^{30}$ UCELAY, Enrique. Estudios críticos de oratoria forense. El foro y su elocuencia en Francia. Conferencias dadas en la Institución Libre de Enseñanza y su clase de Historia y modelos de la oratoria forense, seguidas de algunas de las principales defensas de los más célebres abogados franceses, traducidas por el mismo. Madrid: Imprenta de la Revista de Legislación, 1880; do mesmo autor - UCELAY, Estudios sobre el foro moderno, cit. 
desencadeadas na prestação verbal. E então nos deparamos com os problemas do gesto ${ }^{31}$.

Desde logo, os exercícios declamatórios do jurista educaram o timbre e a inflexão da voz ("modulações que são dadas à voz, para expressar as diferentes afeições da alma") ${ }^{32}$, ao mesmo tempo que ajudavam na vigilância dos movimentos, pois, como sabemos, "deverá declamar de memória [...] falando, poderão dirigir com desembaraço o gesto $\mathrm{e}$ todos os movimentos" ${ }^{33}$. Então, fazia sentido que o aprendiz perorasse "se há proporção para isso, na presença de um mestre de declamação", já que "conhecida a teoria da expressão cênica, nada é mais fácil do que aplicá-la em menor escala às lutas da palavra"; no entanto, mesmo contando com atores do nível de Julián Romea para marcar a pauta ${ }^{34}$, subsistia ainda a necessidade de aprender a gesticular de acordo com os usos admitidos no foro: "o decoro e a circunspeção devem presidir o debate, e o orador deve procurar com grande cuidado não confundir nunca a linha da discussão com a de ofensa" ${ }^{35}$. Seguramente, também agora a observação do modelo ao vivo, melhor que a leitura de um discurso transcrito, resultava insubstituível e, por isso, o Ministério de Graça e Justiça autorizou a presença de advogados-aprendizes nas vistas, ao entender, com toda razão, que "a melhor escola prática para

\footnotetext{
${ }^{31}$ Cf. em geral - BREMER, Jan; ROODENBURG, Herman (ed.). A Cultural History of Gesture. Ithaca (N.Y.): Cornell University Press, 1991.

${ }^{32}$ SAINZ DE ANDINO, Elementos de elocuencia, p. 183.

33 Ibid., p. 35. Ainda - LEÓN Y OLARIETA, Consideraciones filosóficas, p. 143 et seq., onde sobre a "arte de la declamacion... que contribuye á dominar al auditorio, no solo con las impresiones que recibe por el sentido del oido, sino tambien por el de la vista." Sobre esta base se recomienda el uso educativo de los espectáculos teatrales ("observando con discernimiento y acierto el modo cómo los actores escénicos realizan las concepciones del arte", p. 44), ainda que protestando em seguida que "no es nuestro ánimo el tratar la cuestión bajo el aspecto moral y social". Não é assim casual que Cortina adquirisse (por mais de 13.600 reais à época) um palco no Teatro Cômico de Sevilha (PETIT, Biblioteca, archivo, escribanía, p. 357, n. 77).
}

os letrados que se dedicam à nobre carreira do foro é o foro mesmo, onde diariamente se controvertem importantes questões de direito entre aqueles de maior antiguidade e renome, e onde frequentemente tem lugar as vistas de causas célebres, nas quais tomam parte oradores experientes e brilhantes" (R. O. 7 de junho, 1863 - "Mandando que se designe lugar decoroso para os advogados que concorram aos debates judiciais").

Alguns gestos forenses eram memoráveis e universalmente celebrados, concretizando-se em prerrogativas próprias do ofício. Parece que foi o caso da obstinação juvenil em cobrir-se ante os juízes que tinham Francisco de Castro y Orozco, futuro Marquês de Gerona e irmão mais novo do lembrado José, ao relatar por primeira vez na Real Audiencia de Granada; o protesto do inexperiente advogado quanto a antigas tradições que assim o permitiam, contra as contínuas chamadas à ordem do tribunal que se estabeleceram por uma R. O. de 5 de maio, 1836 , (meio) permissiva de levar gorra na cabeça. De forma similar, as conferências de Ucelay sobre advogados franceses registravam a veneração supersticiosa à toga de certos oradores no país vizinho, como o maior dos Dupin, glória forense em tempos de Luís Felipe de Orleans, e autor de uma obra canônica sobre advocacia, mil vezes

${ }^{34}$ ROMEA, Julián. Manual de declamación para uso de los alumnos del Real Conservatorio de Madrid. Madrid: F. Abierzo, 1859 - versão elementar, publicada em 1859 sob a socorrida forma 'oral' do catecismo, de suas prévias Ideas generales sobre el arte del teatro (1858). Não deixa de ser proveitoso repassar as páginas de Romea, por exemplo p. 53 et seq. (sobre dotes do ator), p. 61 et seq. ("da voz"), etc. em leitura cruzada com as partes correspondentes de López e de Sainz de Andino; seria de interesse, inclusive, por em relação com a devoção dos advogados espanhóis ao foro de França e a admiração dos atores pátrios pela cena francesa (assim - ROMEA, p. 72 et seq. sobre Talma). Ao final de contas, sabemos graças a Francisco de Cárdenas que a gente acudia em Sevilha às vistas judiciais "como si asistiesen a una funcion de teatro".

${ }^{35}$ SAINZ DE ANDINO, Elementos de elocuencia, p. 35; LÓPEZ, Lecciones de elocuencia, I, p. 114, 131. 
traduzida e colecionada, a quem "lhe houvessem vocês visto prontamente deixar-se em pedaços, se necessário fosse, em defesa de sua toga e barrete; o que na verdade não deixa de ser heroico" ${ }^{36}$. $\mathrm{Na}$ realidade, além de ser um símbolo profissional com a intenção ínsita, então, do obrigado gesto de vesti-la - o uso da toga teve muito a ver com a atuação forense, já que a vestimenta estava desenhada para permitir ao advogado uma eficaz gesticulação: ao menos, é assim que explico a rara preferência espanhola por uma toga com mangas "sem vuelecillos e curtas para não passar o cotovelo" (R. D. 28 de novembro, 1835, art. 4).

O uso da toga e da gorra, a regulação minuciosa dos tratamentos de respeito, o lugar reservado ao letrado... questões que abordava a legislação contemporânea entravam, não apenas lato sensu, neste capítulo obscuro do gesto profissional: por exemplo, o espaço destinado ao advogado na sala de vistas e o toucado que cobria a cabeça eram símbolos irrenunciáveis de seu status elevado ${ }^{37}$. Agora, em um sentido mais preciso, a maniera do forense deve ser colocada em relação com a oralidade intrínseca de suas intervenções. Se os tratados de retórica sugeriam ao advogado que declarasse poemas para liberar o gesto, tal conselho está relacionado a outra advertência formulada pela mesma literatura, unânime em recomendar a eloquência espontânea (a "improvisação") no momento de pronunciar o discurso. O que supunha desde logo não ler, isto é, nunca escrever previamente o relatório. "Viuse uma vez que os advogados levaram seus relatórios escritos e se contentaram em lê-los ao pé da letra; mas estes são casos extraordinários

\footnotetext{
${ }^{36}$ UCELAY, Estudios críticos de oratoria forense, p. 218. Cf. ainda: RIANT, Hygiène des orateurs, p. 135 et seq.; com insistência na liberdade que dá a robe frente ao traje moderno de pescoço e gravata e a conseguinte prisão do tórax e da garganta; o mal da toga (não falemos já das perucas) é que aumenta perigosamente o calor corporal do orador.

${ }^{37}$ Cf. "Abogado". In: Enciclopedia española de Derecho y Administracion, ó Nuevo Teatro Universal de la
}

[...] Desventura-se muito o orador que que lê o seu discurso, porque nem se lhe descobre o jogo da fisionomia, nem tem desembaraço em seus movimentos; além do que nas discussões judiciais ocorrem, no próprio ato, de ver o pleito mil incidentes que não poderiam ser salvos, se o advogado houvesse de sujeitar-se ao que trouxesse escrito, sem tirar nem pôr" ${ }^{\prime 3}$.

O parágrafo anterior sintetiza à perfeição a tensão oratória do perfeito advogado. Não apenas por emitir a palavra, mas, acima de tudo, por fazê-lo sem ler, o letrado vivia ("sem se desgraçar") a experiência profundamente oral de dizer o direito. Só assim se conseguia "descobrir o jogo da fisionomia", aquele "desembaraço nos movimentos" característico de um bom advogado; uma expressão gestual nada gratuita, por certo, pois se tratava de de(mo[n]strar) a cara descoberta e com um gesto convencido de que a justiça lhe assistia a seu patrocinado, que o pleito, interesses individuais à parte, continha "ingerida, no negócio de um particular, a causa de toda a sociedade" 39 .

Colocados a imitar dos mestres a solução ideal, insinuada, desde logo, nos cursos de Ucelay, consistia em unir a observação direta dos vivos à leitura atentíssima dos mortos (e outra vez Ucelay, que escreve nos anos oitenta, tinha que lamentar a agrafia de Cortina, falecido na década anterior $)^{40}$; além disso, o estudo tranquilo dos relatórios escutados e "vistos" foi certamente benéfico. Mas as coisas não parecem tão simples, porque a impossibilidade material de reduzir o gesto a signos foi acrescentada à relação, pouco

Legislacion de España é Indias. T. I. Madrid: Tipografía general de D. Antonio Rius y Rosell, 1848. p. 82 et seq.

${ }^{38}$ SAINZ DE ANDINO, Elementos de elocuencia forense, I, p. 166.

${ }^{39}$ Ibid., p. 51.

40 "Habla con la corrección de un libro, con el aplomo de un jurisconsulto, y con la destreza de un hombre que ha empleado la mayor parte de su vida en los debates judiciales y políticos", disse a respeito de Cortina seu amigo Joaquín María López (LÓPEZ, Lecciones de elocuencia, II, p. 113). 
pacífica, do verbo forense com a arte da taquigrafia.

A essa arte devemos o acesso a muitos discursos jurídicos pronunciados em um século liberal. Pálidos sucedâneos de intervenções orais, são textos que, por mais que os leiamos hoje, nunca foram rigorosamente escritos. Livros falsos, com os quais temos que lidar com muito cuidado para superar nossos preconceitos tipográficos, mas também verdadeiras dissertações de doutorado ou acadêmicas, autênticos relatórios, genuínos cursos de lições, causas mais ou menos célebres, discussões ocorridas em câmara parlamentar [...] Milhares de palavras, em suma, capturadas e finalmente impressas graças à intervenção do estenógrafo.

Devo frustrar uma história - a da taquigrafia e seu desenvolvimento na Espanha de vivíssimo interesse para efeitos dessas páginas. Basta saber que os mil e um sistemas de escritura veloz, a partir de sua vã pretensão de sincronizar a escritura com a palavra enunciada, nos colocam diante de uma categoria improvável, onde se misturariam, para confundir-se, a dimensão temporal da fala e a dimensão espacial do escrito. A partir dessa perspectiva, o sonho taquigráfico abandona o mundo das rotinas burocráticas para ingressar com honras nos círculos em que vivem, por assim dizer ao estilo de Ong, as Interfaces of the Word ${ }^{41}$.

A relação de taquigrafia com o direito salta à vista, sobretudo se ao direito o enfocamos a partir de sua possibilidade mais primorosamente diacrônica, isto é, a partir de uma concepção processual. Postos no transe de documentar um direito que emana da palavra, será quando desenvolva seus melhores recursos uma grafia concebida para pegá-lo sob a forma de texto; os

\footnotetext{
${ }^{41} \mathrm{ONG}$, Walter. Interfaces of the Word. Studies in the Evolution of Consciousness and Culture (1977). Ithaca, London: Cornell University Press, 1982.

42 MHARTÍN GUIX, Enrique. Estenotipia universal. Madrid 1903; também "Taquigrafía". In: Enciclopedia Vniversal Ilvstrada Evropeo-Americana, LIX (1928).
}

debates nas Cortes, mas também os trâmites orais do juízo, oferecem as melhores ocasiões de encontro entre o verbo jurídico e o documento que deve recolhê-lo fielmente, com a taquigrafia como um mediador natural. E, com efeito, os estrados do foro e os assentos das câmaras supostamente continham, segundo o raciocínio dos interessados, toda a história daquela técnica endiabrada: desde suas origens nas "notas tironianas" devidas à habilidade de Tiro, o liberto de Cícero a quem devemos a conservação de seus discursos, até a manutenção da tradição graças à Igreja, que taquigrafou os processos dos mártires para a edificação dos fiéis, chegando finalmente ao renascimento moderno da arte graças à instituição parlamentar, com o obrigatório capítulo britânico dedicado aos primeiros 'sistemas' e seu desenvolvimento progressivo na França, Alemanha, Espanha..., aqui graças ao trabalho de um exaltado liberal (Francisco de Paula Martî́) ${ }^{42}$.

Agora, levada por sua aspiração de escrever com a mesma velocidade com que se fala, a taquigrafia tinha ainda que lutar com a irredutibilidade quirográfica do discurso declamado. E então se abria uma brecha dilatada entre o taquígrafo e o orador. Em primeiro lugar, o taquígrafo deveria vencer a dificuldade objetiva de recolher com exatidão um discurso dito a toda velocidade (pois "a taquigrafia é um meio imperfeito [...] de toda maneira insuficiente para seguir a velocidade de um discurso") ${ }^{43}$. Talvez a solução menos pior fosse a seguida por Ucelay com os discursos forenses de Pacheco, isto é, converter o aprendiz do foro em um taquígrafo amateur e se atrever assim com os relatórios e defesas. Ainda que circulassem obras que anunciavam a "taquigrafia judicial [...] para uso

Madrid: Espasa-Calpe, 1991. p. 513-527; assim como "Martí, Francisco de Paula". In: ibid. XXXIII (1917), p. 448-449. Cf. PASCUAL Y BELTRÁN, Ventura. El inventor de la taquigrafía española: Francisco de Paula Martí. Valencia: Tipografía del Carmen, 1926.

${ }^{43}$ LÓPEZ, Lecciones de elocuencia, II, p. 48. 
dos advogados, procuradores, escrivães e demais funcionários dos Tribunais de Justiça", parece que a breviscritura, com suas muitas limitações, era técnica com seus próprios profissionais ${ }^{44}$.

Contra tão laboriosa, jogavam ademais os preceptores que consultamos. Por exemplo, as Lecciones de elocuencia de Joaquín María López abordavam a dificuldade de tratar da oratória parlamentar, mas suas considerações, que por certo documentam insólitos usos de leitura, seriam aplicáveis por completo aos discursos forenses. Fora da capital, a notícia da vida política só era possível graças às crônicas parlamentares que apareciam nos jornais; pois bem, "chegados que são ao final os anelados papeis públicos, um leitor escolhido se apodera deles, busca antes de tudo as sessões das Câmaras e as lê com voz repousada e solene, enquanto que todos escutam em recolhido silêncio e auribus erectis, como os Hebreus ouviam a leitura dos livros sagrados", embora essa esforçada versão popular do discurso proferida nas Cortes, com sua deliciosa intenção verbal, não fosse suficiente para imitar nem sequer o ambiente original e o tom da oração. E a culpa era do taquígrafo: "os maus discursos ganham na versão do taquígrafo [...] mas os bons perdem o melhor que tinham [...] porque a arte recolheu somente a sua côdea, sua parte material, enquanto que se lhe escapou a parte espiritual" 45 .

A exatíssima referência à colaboração dos taquígrafos com os maus oradores abunda numa questão que, nos termos de Walter Ong, poderíamos expressar com a máxima (e com um pequeno anglicismo) segundo a qual transcrever

\footnotetext{
44 MHARTÍN GUIX, Enrique. Curso completo de taquigrafía judicial. Para uso de los abogados, procuradores, escribanos, secretarios judiciales y demás funcionarios de los Tribunales de Justicia. Ajustado á las prácticas forenses con sujeción al sistema Martí único que siguen los Taquígrafos de los Cuerpos Colegisladores y arreglado al nuevo método de escritura veloz denominado Taquigrafía abreviada que aventaja con brevedad, claridad y perfección á cuantos se han publicado, y permite escribir con una velocidad superior á todas las conocidas en el breve espacio de un año. Madrid: A. San Martín, 1899.

${ }^{45}$ LÓPEZ, Lecciones de elocuencia, II, p. 47 et seq.
}

é editar. Pois o espanholíssimo "sistema Marti', ou seja, esse reputado "sistema geométrico coordenador" que pretendia escrever com tanta velocidade quanto se fala, tinha ademais o desafio, nada pequeno, de fazê-lo com a mesma claridade que a escritura comum. E aí residia precisamente o problema. Aqueles que teorizaram sobre essas coisas não hesitaram em recomendar aos taquígrafos que adquirissem uma formação geral o mais completa possível, pois eles eram os protagonistas anônimos da versão impressa do discurso: "não é suficiente reproduzir com exatidão a palavra falada, mas é necessário surpreender os equívocos que padeça o que fala e saná-las desde logo". Proposto assim "o labor do taquígrafo, puramente intelectual, não pode ser substituído por uma ação mecânica em nenhum caso" e então pareciam pouco mais que trastes inúteis esses potenógrafos (1830), esses estenógrafos impressores (1869), esses glossógrafos (1883) e até o moderníssimo estenodátilo de Lafaurie: pois destas máquinas raras com nome de sáurio pré-histórico "os discursos saem com todos os defeitos de dicção com que os oradores se expressam muitas vezes, e se deve corrigi-los depois de impresso o discurso, com o que se joga a perder todo o trabalho" 46 .

Presa que fosse a palavra forense ou política, o resultado conduzia finalmente a um escrito cujos "proprietários" não estavam em absoluto determinados. A metáfora da propriedade intelectual, elaborada para dar resposta jurídica a uma relação quiro/tipográfica

${ }^{46}$ Cf. "Taquigrafía". In: Enciclopedia Vniversal... LIX, p. 513. Cf. GARRIGA MARILL, Pedro. Taquigrafía con $s u$ comparacion e historia universal (1864). $5^{\mathrm{a}}$ ed. Barcelona: Imprenta Jaime Jepús, 1887. p. 19 - sobre "El taquígrafo perfecto.- El taquígrafo, para desempeñar su cometido con perfección, no debe limitarse á devolver con fidelidad las palabras del orador; es menester, además, que sepa suplir tanto los defectos de estilo y corregir los errores de concepto que en el discurso tomado se encuentran, como las interrupciones de su propia pluma, ineludibles á las veces; para lo cual necesita, sino profunda, muy variada instrucción". 
entre o literato e seu livro, só de maneira muito forçada poderia estender-se ao discurso verbal, sobretudo quando se tratava de servir, com a palavra, a república 47 . Expressado resumidamente, um advogado não poderia simplesmente transcrever suas alegações e publicá-las, uma vez que sua devoção à causa coletiva o obrigava a obter previamente a permissão do juiz; além disso, sua intervenção pro parte ainda justificava o consentimento adicional da mesma. Sobre a questão, pronunciou-se a lei de propriedade literária de 1879 (10 de janeiro, a lei anterior de 1847 silenciava o extremo) quando atribuiu às partes a propriedade "dos escritos que se apresentaram a seu nome em qualquer pleito ou causa" (art. 16), ainda que outra vez as coisas não estavam claras, pois a exigência de obter permissão do tribunal para a publicação nos remete a um interesse objetivo na preservação da justiça e seu decoro que vivia, mas além dos negócios de parte, em cada litígio concreto; fazêlo evidente mediante a eloquência era, nós o sabemos, um dever ineludível do profissional do foro, e, por isso, tinha perfeito sentido para o mesmo artigo 16 que submetesse ao consentimento dos juízes e das partes a coleção "[d]os escritos ou defesas" que quisesse publicar o advogado. Entretanto, as partes pareciam esfumar-se à hora de publicar "cópias ou extratos de pleitos fenecidos”, já que somente valia agora a autorização dos juízes com mais ou menos

47 BENEDUCE, Pasquale. Il corpo eloquente. Identificazione del giurista nell'Italia liberale. Bologna: Il Mulino, 1996. p. 359 et seq. (sobre "Il diritto pubblico dell'arringa").

48 DANVILA Y COLLADO, Manuel. La propiedad intelectual. Legislación española y extranjera, comentada, concordada y esplicada según la historia, la filosofía, la jurisprudencia y los tratados. $2^{\mathrm{a}} \mathrm{ed}$. Madrid: Imprenta de La Correspondencia de España, 1882 - notável obra doutrinal do que foi o impulsionador, nas Cortes, do texto legal aludido.

49 Penso nas manifestações de Antonio Cánovas del Castillo, recolhidas no final de século por - LÓPEZ MUÑOZ, Antonio. Principios y reglas de la elocuencia en la oratoria, la declamacion y la lectura. Lecciones explicadas en la Escuela de Estudios Superiores del Ateneo discriminações e restrições (art. 17-18; o regulamento da lei voltava a este ponto, ao ordenar ao juiz antes de conceder a permissão dar audiência ao ministério fiscal, assim como às partes, de intervir no pleito: art. 12, R. D. 3 de setembro, 1880) ${ }^{48}$. Contudo, ficava no ar o suposto de maior relevância prática, a saber, a publicação na imprensa cotidiana de algum discurso escutado ou das atuações mais vistosas de uma causa judicial; mas a lei dispôs em seu art. 11 que os discursos parlamentares, desde logo "propriedade" do orador, "só poderão ser reimpressos sem sua permissão ou de seu direitotenente no Diario de las Sesiones del Cuerpo Colegislador respectivo e nos periódicos políticos", previsão esta última - culturalmente inevitável - que esvaziava por completo a proclamada "propriedade"; ao fim e ao cabo, a prestação verbal, forense ou política que fosse, não só tinha o orador como dono e protagonista: a improvisação como fundamento do discurso fazia com que o público presente, com suas reações sempre emotivas, fosse também um elemento necessário da peça declamada ${ }^{49}$. De resto, não necessitamos disputar o terreno com os experts em teoria da comunicação para compreender que o periódico resulta ser um impresso especial, localizado perto - talvez apenas a um passo de distância - da expressão verbal. A espessura temporal do periódico arrastou-o para o campo da oralidade, onde naturalmente se cruzava com o

de Madrid durante el curso de 1897 á 1898. Primera serie. Madrid: Pedro Núñez, (1899?). p. 84: “yo no sé hablar ante pocas personas; yo, para hablar, necesito al público; y á tal extremo llego en esto, que una vez que en ocasion solemne tuve que pronunciar un breve discurso en Palacio ante contadísimas personas, lo escribí para leerlo, temeroso de que la falta de público me impidiera salir airoso del empeño". Uma pequena história oral que López Muñoz apostilava seguidamente também de forma pouco ou nada quirografaria: "dijo aquel grande orador una verdad, y consagró con aquella manifestación un principio de toda preceptiva oratoria; pero tenía su manifestación y tiene más valor que la de una consideracion doctrinal escrita, porque era el texto vivo, la encarnación personal y la comprobación irrecusable de la doctrina misma" (p. 84-85). 
discurso forense, a causa célebre ou o debate nas Cortes. E assim se explica, não somente a distância muito curta entre a oratória e o periodismo, mas também a participação ativa do advogado liberal na redação e no colocar em marcha periódicos e revistas ${ }^{50}$.

Estas afirmações não estão de todo completas, pois os produtos da imprensa cotidiana ainda hoje são textos muito "orais", embora não se assemelhem muito aos seus maiores: estes mais combativos, numerosos e sectários. Com efeito, para compreender o significado jurídico (mais precisamente, judicial) dos velhos periódicos, devemos ainda introduzir a noção do público ${ }^{51}$. No sentido que nos interessa, que responde $a$ grosso modo às análises pioneiras de Jürgen Habermas, o público é o âmbito ideal onde se joga a relação entre a sociedade civil e o Estado. Nascido como uma seleta opinião nos salões do séc. XVIII e canalizada pelos fracos mecanismos de participação sucessivos (em vão: pois se estava sempre à beira da eclosão revolucionária), o público ("o público") representou aquele princípio de unidade necessário a um corpo social receado por opções antagônicas (despotismoconstituição, regime autoritário-governo representativo, monarquia-república, e mais um longo etcétera), mas também forneceu o argumento inapelável que poderia ser invocado tanto na defesa quanto no ataque do Estado, tanto dentro quanto fora de suas instituições: a ideia de um Estado entendido como integração (Rudolf Smend), a definição do ente político exatamente como um "Estado integral" (cf. art. 1,

\footnotetext{
${ }^{50} \mathrm{E}$, com efeito, a primeira reflexão teórica sobre o periodismo na Espanha liberal tocou a um jurista que conhecemos, fundador de revistas jurídicas e de periódicos políticos: Joaquín Francisco Pacheco (La Abeja, 1834; Boletín de jurisprudencia y lejislación, 1836) que ingressou na Real Academia Española (1845) com um discurso Sobre el periodismo en sus relaciones con la literatura.

${ }^{51}$ Cf. KARPIK, Lucien. Lawyers and Politics in France, 1814-1950: The State, the Market, and the Public (1988). In: SUGARMAN, David (ed.). Law in History. T. II.
}

Constituição da República Espanhola, 1931) será algo do século XX.

Até esse momento, a nova, decisiva opinião pública teve que dotar-se de meios de expressão para deixar ouvir sua voz ante as instâncias oficiais. Meios às vezes violentos (motins, greves, pronunciamentos, partidas legitimistas), às vezes, na maioria, pacíficos (as músicas das canções e as festas, as cores de uniformes e bandeiras, as mais ou menos forjadas eleições, etc.). Mas sobretudo "a opinião pública" se fez presente nas colunas dos periódicos e pode ser escutada graças à eloquência de uns quantos homens capacitados, exatamente chamados - sem equívoco possível - homens públicos. E o advogado, sempiterno profissional da palavra, titular de um velhíssimo saber oratório forjado como sabemos no modelo do discurso forense, tornou-se assim o porta-voz natural do público e sua opinião, com incessantes discursos que a imprensa se encarregava de amplificar: ninguém como um expert em controvérsia oral para vocalizar a experiência agônica do público.

Em realidade, a celebração das liberdades profissionais do advogado e o louvor de uma livre defesa (ou, na versão negativa, o compunção do advogado nacional ante a situação degradada dos colegas alemães e russos: pouco menos que funcionários do Estado), presentes em qualquer texto de cultura forense, não foram muito mais que uma elegante metáfora das próprias liberdades; pelo menos, os direitos encontraram o mais firme bastião contra a arbitrariedade do poder na atividade forense e em uma bem ordenada advocacia ${ }^{52}$. Por isso foi tão frequente o

Aldershot: Darmouth, 1996. p. 215-244, em particular p. 231 et seq ("Representatives and the Public").

52 Por exemplo, a voz "Avocat" do difundidíssimo Répertoire (1846) de Dalloz ( «avec la collaboration de M. Armand Dalloz, son frère» - DALLOZ. Répertoire méthodique et alphabétique de législation, de doctrine et de jurisprudence... T. V. Paris, au Bureau de la Jurisprudence Générale du Royaume, 1846. p. 457-595) arranca com a seguinte definição: “l'avocat... est celui qui, après avoir obtenu le grade de licencié en droit, se charge de dé[f]endre 
desempenho das dignidades parlamentares por parte dos advogados, com a difícil distinção entre a causa da advocacia e a causa da política: "a profissão do orador é um ministério respeitável, que requer grandes virtudes e nobres sacrifícios para o seu bom desempenho. Ora advogue perante os tribunais... ora na tribuna defenda os interesses dos povos e o decoro nacional; ora predique a moralidade evangélica no púlpito; ora derrame na cátedra a luz do ensino, sempre a missão do orador é árdua, importante e fecunda" ${ }$.

Assim, podemos compreender finalmente o significado cultural da atenção jornalística às palavras do advogado e às coisas da justiça. E assim se justifica também que essas palavras decisivas se difundissem com o imediatismo, a agilidade temporal e a discreta fidelidade que só os jornais garantiam. Pois o incessante arranjo jurídico das tensões públicas provocou processos de grande repercussão, onde a discussão do caso serviu para tornar visível (e melhor ainda: audível) o clamor do público e as sacudidas de sua opinião. Um assassinato, por exemplo, o horrível

oralement ou par écrit, devant les tribuneaux, l'honneur, la vie, la liberté et la fortune des citoyens. C'est assurément l'une de plus nobles, des plus libres en même temps que des plus indispensables professions de tout ordre social bien constitué", e acrescenta, tomando-o da Vie de Dumoulin de Henrion de Pansey, a seguinte valoração: "libre des entraves qui captivent les autres hommes, trop fier pour avoir des protecteurs, trop obscur pour avoir des protégés, sans esclave et sans maître, ce serait l'homme dans sa dignité originelle, si un tel homme pouvait encore exister sur la terre" (p. 457). A Enciclopedia española de Derecho y Administración dirigida por Arrazola (s. v. "Abogado", I, pp. 82-83), oferece dois anos mais tarde uma tradução compendiada: "título que se da á los profesores que despues de haber recibido el grado de licenciado en jurisprudencia, se consagran á defender por escrito, y ante los tribunales establecidos por las leyes, los intereses mas respetables de los ciudadanos, como el honor, la vida, la libertad y la fortuna". Mas não se trata agora de descobrir as fontes de Arrazola, mas sim compreender as coordenadas culturais que fizeram possíveis certos empréstimos. uxoricídio cometido na Calle de la Justa (1862), que tanto fama reportou a Pacheco nos últimos anos de sua vida, poderia oferecer a melhor ocasião para debater sobre a pena de morte, recordar a existência dos seres desvalidos, colocar em dúvida a imparcialidade do promotor ou do juiz, demonstrar os defeitos da regulação arcaica dos procedimentos... Poderia até motivar a convocação, que teve lugar por primeira vez na Espanha (e uma das primeiras na Europa), de um Congresso de jurisconsultos (1863) onde os advogados, depois de suplantarem nada menos que o nome da instituição parlamentar, à base de muitíssimas palavras exerceram seu direito a discutir matérias de envergadura (a codificação, a liberdade no ato de testar, o júri...) amparados naquela representação do público que naturalmente lhes correspondia: na expressão inequívoca do mesmo Pacheco (e segundo versão jornalística da célebre causa apenas evocada) o advogado nunca "nega a importância dessa opinião [pública]... porque ele a representa... e sabe render-lhe o acatamento que merece" ${ }^{, 54}$.

53 CORRADI, Fernando. Lecciones de oratoria pronunciadas en el Ateneo Científico y Literario de Madrid (1843). $2^{\mathrm{a}}$ ed. Madrid: Eduardo Mengíbar, 1882. p. 40. E tem então sentido que contasse com um capítulo específico de "Direitos políticos" a voz "Abogados" de: ARRAZOLA, Lorenzo (dir.). Enciclopedia española de Derecho y Administracion, I, p. 134-135. Ao fim e ao cabo, num sistema constitucional tão curto de garantias, como o foi o Estado liberal, a livre defesa e a livre prensa foram fungíveis como instrumentos de denúncia e controle popular dos excessos do poder.

${ }^{54} \mathrm{Cf}$. [ESTÉR, Cayetano de]. Congreso de jurisconsultos celebrado en Madrid, los días 27, 28, 29, 30, y 31 de octubre de 1863. La Escuela del Derecho, n. 3, 1863, p. 97-163. O Congresso nasceu de uma anônima carta, na realidade obra do advogado Francisco de Paula Canalejas, aparecida em $L a$ Revista Ibérica, um periódico de krausistas fundado (1861) pelo próprio Canalejas, dirigida a Pacheco invitando-o a convocar o congresso em sua condição de glória do foro nacional; a vinculação entre esta iniciativa e as alegações de Pacheco na célebre causa que conhecemos a estabelece com luxo de detalhes Enrique Ucelay (UCELAY, Estudios sobre el foro moderno, p. 182), com publicação da carta (p. 182 et seq.) "por su notable y gallardo estilo", a partir do texto daquela Revista, a cuja redação o autor dizia pertencer. Permito-me agregar que o advogado Canalejas era catedrático de Literatura na faculdade de Letras e, sem 
E, no entanto, o elevado compromisso ético da advocacia forense e a consequente vizinhança entre tribunais e parlamentos condicionaram seriamente a determinação legal do direito. De modo paralelo às teorias sobre as diferenças entre o discurso de tribuna (política) e a oratória forense (direito), abriu-se passo na triste história do Estado liberal uma concepção da atividade legislativa que manteve no mínimo as atribuições dos órgãos parlamentares. A insistência dos autores sobre a natureza peculiar do verbo forense, em uma atividade oratória dominada pela análise, tranquilidade, lógica, raciocínio... Assim então contraposta à exaltação poética da linguagem da "tribuna", celebrou os mesmos valores que se julgavam necessários para a formação dos códigos e demais leis principais, com a consequente preferência, no momento de elaborá-los, do técnico "frio" que trabalhava para o governo sobre o acalorado "político" que gritava no parlamento. "Uns corpos numerosos como as nossas Câmaras são os menos aptos para a formação de semelhantes leis", argumentou o recordado Pacheco. "Exigem estas em seus redatores, em quantos possam influenciar com um voto em sua confecção, não apenas conhecimentos especiais na matéria, os quais seria absurdo procurar em uma assembleia tão numerosa, mas até mesmo uma certa homogeneidade de princípios, um certo espírito sistemático, que não podem ser encontrados senão em um pequeno número de homens dedicados a esta muito principalmente. Mas a grande, a imensa maioria de todo corpo político deliberante, há de encontrar-se em um muito distinto caso. É

dúvida, andava já com a cabeça posta em seu notável Curso de Literatura General (I: La poesía y la palabra, 1868; II: La Poesía y sus géneros, 1869). Para as palavras de Pacheco, vide a crônica judicial de El Pensamiento Español (Madrid, miércoles, 1 de octubre, 1862).

${ }^{55}$ PACHECO, Juan Francisco. Códigos. Su formación. Su discusión. Boletín de Jurisprudencia y Legislación, n. 1, 1836, p. 115-121.

${ }^{56}$ FUENTES, Juan Francisco. La formación de la clase política del liberalismo español: análisis de los cargos impossível supor que seja composta por advogados, e advogados de grande mérito. E não se deve sempre esperar a prudência necessária, para que cada qual se anule naqueles pontos que não entenda. Pois bem! Não pensam muitos sinceramente que conhecem até o mais íntimo as ciências que apenas saudaram?"55. Pouco importa que os experts em Direito, por tudo que se argumentou antes, ocupassem as assembleias "legislativas" "56, pois esse modo tão limitado de entender suas competências naturais se expandiu por toda parte. "Eu, que já tenho bastante idade para ter visto muitos desenganos", expressava uma velha raposa do liberalismo espanhol, "estou curado de paixão; e se bem venero e acato esta classe de governos representativos, acredito plenamente que não os vejo como o instrumento mais apropriado para governar [...] São excelentes como meios políticos. Mas não são bons em formar leis" ${ }^{\prime \prime}$.

Os escrúpulos contra as câmaras "como meios políticos" reproduziam, então, os caracteres do verbo parlamentar, em franco contraste com os requisitos do bem dizer forense. Portanto, não é de surpreender que, quando se encomenda um retrato de Cortina para a galeria de presidentes do Congresso dos Deputados, aparecesse o grande advogado - caso nada comum nessa galeria - revestido de toga profissional ${ }^{58}$. Suas conhecidas virtudes (temperança, modéstia, eloquência, prudência) e capacidades (fino raciocínio, caráter pacífico) eram também os atributos ideais das novas leis: justas, prudentes, fortes, moderadas... com a corporação forense comprometida com sua fatura

públicos del Trienio liberal. Historia Constitucional, n. 3, 2002, p. 19-37 (http://hc.rediris.es/03/index.html) - para mencionar somente o primeiro período que produziu códigos em Espanha: um projeto - muito original- de Código civil (1821) e um - efêmero - Código penal (1822).

57 ALCALÁ GALIANO, Antonio. Lecciones de derecho político (1843). Ed. Ángel Garrorena. Madrid: Centro de Estudios Constitucionales, 1984. p. 124.

${ }^{58}$ El retrato (1872) é obra tardia do pintor Eduardo Rosales (1836-1873) e mede 130 x $90 \mathrm{~cm}$. 
e aplicação ${ }^{59}$. E a palavra jurídica que não deveria ser escrita, a teor da "mania" de Cortina "contra a publicidade" (a oratória forense a serviço do singular cidadão, cultivada com os livros que conhecemos), resultou perfeitamente compatível com a escritura de códigos que, ao contrário, não deviam falar-se: textos normativos inefáveis, alheios a um parlamento limitado a confiar a fatura dessas grandes leis aos advogados mais experts, munidos das pertinentes leis de autorização: "criaturas os Advogados que vivem no seio das distintas capas sociais, vêm a ser individualmente outros tantos órgãos das petições, reclamações, ecos e clamores das várias classes e partidos; e em suas agremiações, acumulam e fomentam a soma de todos os conhecimentos morais, legais e políticos [...] cada Colégio de Advogados [...] assume em si o sufrágio da opinião e autoridade da ciência"60.
"Também influenciava muito no estilo e na textura de suas primeiras perorações", se dizia de Cortina, "e de quantas depois pronunciou no parlamento, sua profissão de advogado. Pois, se bem em ocasiões tenha remontado no estilo [...] geralmente dominou em sua oratória a tinta, o colorido da oratória do foro, de per se tranquila, analítica, lógica e racional [...] Falta a Cortina, talvez, aquele vigor de entonação que sustenta o discurso e não permite ao adversário retroceder ou respirar em combate; falta-lhe, indubitavelmente, aquela emoção interior que se comunica aos demais, quando o mesmo orador a experimenta" ${ }^{\prime 61}$.

Mas um orador sem emoções realmente é um legislador. Até esse ponto chegaram, com suas vistosas receitas sobre a profissão do foro, os livros e as antologias para o uso de advogados no Estado liberal.

\section{REFERÊNCIAS}

ALCALÁ GALIANO, Antonio. Lecciones de derecho político (1843). Ed. Ángel Garrorena. Madrid: Centro de Estudios Constitucionales, 1984.

ÁlVAREZ ALONSO, Clara. Perfil del jurista romántico español (1834-1855 ca.). In: CONDE NARANJO, Esteban (ed.). Vidas por el Derecho. Madrid: Dykinson - Universidad Carlos III, 2012. BENEDUCE, Pasquale. Il corpo eloquente. Identificazione del giurista nell'Italia liberale. Bologna: Il Mulino, 1996.

BREMER, Jan; ROODENBURG, Herman (ed.). A Cultural History of Gesture. Ithaca (N.Y.): Cornell University Press, 1991.

CASTRO Y OROZCO, José de. Arte Poética de Horacio. Reducida a menos sílabas. Manuscrito anónimo, publicado y anotado por Don... Marqués de Gerona. Barcelona: Tipografía de Narciso Ramírez, 1865.

\footnotetext{
59 TORRES MENA, Juan. Memorial ajustado en el pleito sobre la Codificación que se eleva al Tribunal-Decanato del Ilustre Colegio de Abogados de Madrid. Revista General de Legislación y Jurisprudencia, n. 46, 1875, p. 81-110, uma autêntica alegoria.

60 TORRES, Memorial, p. 109. Cf. MARCUELLO BENEDICTO, Juan Ignacio. La práctica parlamentaria del reinado de Isabel II. Madrid: Congreso de los Diputados, 1986. Inclusive nos casos de maior compromisso com o sistema representativo, em matéria de códigos não se
}

chegou mais além das leis de bases: cf. ROSSI, Pellegrino. Tratado de derecho penal (1829). T. II. Trad. Cayetano Cortés. Madrid: Impta. de don José María Repullés, 1839. p. 333 .

61 RICO Y AMAT, Juan El libro de los diputados y senadores. Juicios críticos de los oradores más notables desde las Cortes de Cádiz hasta nuestros días, con la inserción íntegra del mejor discurso que cada uno de ellos ha pronunciado. T. I-IV. Madrid: Establecimiento tipográfico de R. Vicente, 1862-1866 (T. II, p. 269 et seq.). 
CORRADI, Fernando. Lecciones de oratoria pronunciadas en el Ateneo Científico y Literario de Madrid (1843). $2^{\mathrm{a}}$ ed. Madrid: Eduardo Mengíbar, 1882.

DANVILA Y COLLADO, Manuel. La propiedad intelectual. Legislación española y extranjera, comentada, concordada y esplicada según la historia, la filosofía, la jurisprudencia y los tratados. $2^{\mathrm{a}}$ ed. Madrid: Imprenta de La Correspondencia de España, 1882.

DÍEZ, Jorge. Discurso leído el $1^{\circ}$ de octubre de 1859 , en la solemne apertura del curso de la Universidad de Sevilla por... catedratico propietario de Literatura Latina. Sevilla: Imprenta y Librería Española y Extrangera, 1860.

FERGUSSON, Robert A. Law and Letters in American Culture. Cambridge (Mass.): Harvard University Press, 1984.

FIGUEROLA BALLESTER, Laureano. Derecho político comparado: Lecciones de la Universidad Central, 1859-1860. "Prólogo" de Víctor J. Vázquez.

FUENTES, Juan Francisco. La formación de la clase política del liberalismo español: análisis de los cargos públicos del Trienio liberal. Historia Constitucional, n. 3, p. 19-37, 2002.

GARRIGA MARILL, Pedro. Taquigrafía con su comparacion e historia universal (1864). $5^{\mathrm{a}}$ ed. Barcelona: Imprenta Jaime Jepús, 1887.

KARPIK, Lucien. Lawyers and Politics in France, 1814-1950: The State, the Market, and the Public (1988). In: SUGARMAN, David (ed.). Law in History. T. II. Aldershot: Darmouth, 1996.

LEÓN Y OLARIETA, Fernando de. Consideraciones filosóficas, sobre la elocuencia forense. Esplicaciones dadas por don... Valencia: Imprenta de El Valenciano, 1862.

LÓPEZ SÁNCHEZ, Pedro. Discurso leído por el Dr. ... Catedrático numerario de la Facultad de Derecho ante el claustro de la Universidad de Salamanca el día $1^{\circ}$ de Octubre de 1864 en el acto solemne de la inauguracion de los estudios del curso académico de 1864 á 1865 [Importancia de los crecimientos en la vida científica que se comunica de maestros á discípulos segun ley histórica y nociones filosóficas]. Salamanca: Diego Velázquez, 1864.

LÓPEZ, Joaquín María. Colección de discursos parlamentarios, defensas forenses y producciones literarias. T. I-VII. Madrid: Manuel Minuesa, 1856-1857. Cf. também, entre muitos outros - CASTRO Y OROZCO, José de. Obras poéticas y literárias. T. I-II. Madrid: M. Rivadeneyra, 1864-1865.

Lecciones de elocuencia en general, de elocuencia forense, de elocuencia parlamentaria y de improvisación. T. I-II. Madrid: Imprenta que fue de la Sociedad de Operarios, ahora de D.M. Gabeirós, 1849-1850.

MARTÍNEZ NEIRA, Manuel. El estudio del Derecho: libros de texto y planes de estudio en la universidad contemporánea. Madrid: Dykinson - Universidad Carlos III, 2001.

La regulación de las oposiciones a cátedras universitarias: 1845-1931. Madrid: Universidad Carlos III, 2014. 
MHARTÍN GUIX, Enrique. Curso completo de taquigrafía judicial. Para uso de los abogados, procuradores, escribanos, secretarios judiciales y demás funcionarios de los Tribunales de Justicia. Ajustado á las prácticas forenses con sujeción al sistema Martí único que siguen los Taquígrafos de los Cuerpos Colegisladores y arreglado al nuevo método de escritura veloz denominado Taquigrafía abreviada que aventaja con brevedad, claridad y perfección á cuantos se han publicado, y permite escribir con una velocidad superior á todas las conocidas en el breve espacio de un año. Madrid: A. San Martín, 1899.

MHARTÍN GUIX, Enrique. Estenotipia universal. Madrid 1903; também "Taquigrafía". In: Enciclopedia Vniversal Ilvstrada Evropeo-Americana, LIX (1928). Madrid: Espasa-Calpe, 1991.

MIGUEL ALONSO, Aurora; MARTÍNEZ NEIRA, Manuel et al. Doctores en derecho por la Universidad Central: Catálogo de tesis doctorales 1847-1914. Madrid: Dykinson - Universidad Carlos III, 2018.

MUÑOZ MACHADO, Santiago (ed.). Historia de la abogacía española. T. I-II. Pamplona: Aranzadi, 2015.

ONG, Walter. Interfaces of the Word. Studies in the Evolution of Consciousness and Culture (1977). Ithaca, London: Cornell University Press, 1982.

PACHECO, Juan Francisco. Códigos. Su formación. Su discusión. Boletín de Jurisprudencia y Legislación, n. 1, 1836.

PALOMO, Francisco de Borja. Discurso leido el día $1^{\circ}$ de Octubre de 1867, en la solemne apertura de estudios, por... catedrático numérario de Prolegómenos del Derecho, Historia y Elementos del Derecho Romano. Sevilla: J. M. Geofrín, 1867.

PASTOR DÍAZ, Nicomedes; CÁRDENAS, Francisco de. Galería de Españoles célebres contemporáneos, 1843 (agora consultada em: HERRERO MEDIAVILLA, Víctor. Índice biográfico de España, Portugal e Iberoamérica. $2^{\text {a }}$ ed. München: Saur, 1995.

PETIT, Carlos. Biblioteca, archivo, escribanía. Portrait del abogado Manuel Cortina. In: CONDE NARANJO, Esteban (ed.). Vidas por el Derecho. Madrid: Dykinson - Universidad Carlos III, 2012. RIANT, A. Hygiène des orateurs, avocats, magistrats, hommes politiques, prédicateurs, professeurs, artistes, et de tous ceux qui sont appelés à parler en public. Paris: Baillière et Fils, 1888.

ROMEA, Julián. Manual de declamación para uso de los alumnos del Real Conservatorio de Madrid. Madrid: F. Abierzo, 1859.

SAINZ DE ANDINO, Pedro. Elementos de elocuencia forense (1827). $4^{\mathrm{a}}$ ed. Madrid: Imprenta de la Sociedad de Operarios del mismo Arte, 1847.

TORRES CAMPOS, Manuel. De la reforma de la enseñanza del Derecho en general y en particular de las Academias. Discurso leído en la sesión inaugural del curso de 1890 en la Universidad de Granada. Revista de los Tribunales, n. 22, 1891. 
TORRES MENA, Juan. Memorial ajustado en el pleito sobre la Codificación que se eleva al TribunalDecanato del Ilustre Colegio de Abogados de Madrid. Revista General de Legislación y Jurisprudencia, n. 46, p. 81-110, 1875.

UCELAY, Enrique. Estudios críticos de oratoria forense. El foro y su elocuencia en Francia. Conferencias dadas en la Institución Libre de Enseñanza y su clase de Historia y modelos de la oratoria forense, seguidas de algunas de las principales defensas de los más célebres abogados franceses, traducidas por el mismo. Madrid: Imprenta de la Revista de Legislación, 1880.

Estudios sobre el foro moderno. Conferencias dadas en la Real Academia de Jurisprudencia en el curso de 1882 á 1883 seguidas de biografías y defensas de abogados célebres españoles. Madrid: Viuda de J. M. Pérez, 1883.

Recebido em: 30/12/2018 Aceito em: 30/12/2018 
